\title{
THE MEDIATED EFFECT OF FORMALAND INFORMAL CONTROL ON GOVERNANCE FORMS
}

\author{
Efeito mediador do controle formal e informal na forma de governo \\ Efecto mediador del control formal e informal en la forma de gobierno
}

\begin{abstract}
The present paper employs the perspective of Transaction Cost Economics (TCE) to analyze the relevance of formal and informal controls in selecting the governance form. The evidence supports the influence of frequency, information sharing and relation-specific investments as a cause of control mechanisms, and the effect of these factors on the choice of the governance form, but there is no evidence about the combined interaction between these variables. The present work proposes that there is a mediation effect of formal and informal norms on the relationship between the TCE variables (frequency, information asymmetry and relation-specific investments) and the governance form. We applied Structural Equation Modelling to companies in the telecommunications sector in Spain. Our results confirm the opposite effect of formal and informal controls on the selection of governance forms and the mediation effect of these mechanisms of control on the selection of the governance form.
\end{abstract}

KEYWORDS | Governance forms, integration, formal control, informal control, transaction characteristics.

\section{RESUMO}

O presente trabalho emprega o ponto de vista da Economia dos Custos de Transação (ECT) para analisar a relevância dos controles formais e informais na seleção da forma de governança. A evidência apoia a influência da frequência, compartilhamento de informações e investimentos específicos como causa dos mecanismos de controle, e o efeito desses fatores sobre a escolha da forma de governança. Entretanto não há nenhuma evidência sobre as interações entre essas variáveis. Este trabalho propõe que existe um efeito de mediação das normas informais e formais sobre a relação entre as variáveis da ECT (frequência, informações assimétricas e investimentos específicos) e a forma de governança. A Modelagem de Equações Estruturais é aplicada a empresas do setor de telecomunicações da Espanha. Os resultados obtidos confirmam o efeito oposto de controles formais e informais e o efeito de mediação dos mecanismos de controle sobre a seleção da forma de governança.

PALAVRAS-CHAVE / Formas de governança, integração, controle formal, controle informal, características da transação.

\section{RESUMEN}

El presente trabajo emplea la perspectiva de la Economía de los Costes de Transacción (ECT) para analizar la relevancia del control formal e informal en la selección de la forma de gobierno. Los estudios existentes ponen de relieve la influencia de la frecuencia, la información compartida y las inversiones específicas como causa de los mecanismos de control, y el efecto de estos factores sobre la elección de la forma de gobierno, pero no hay evidencia sobre la interacción conjunta de estas variables. Este trabajo propone que hay un efecto de mediación de las normas formales e informales en la relación entre las variables de la ECT (frecuencia, asimetría de la información e inversiones específicas) y la forma de gobierno. Tras aplicar un Modelo de Ecuaciones Estructurales en el sector de las telecomunicaciones en España, los resultados confirman que los controles formales e informales actúan como mediadores en la relación existente entre las características de las transacciones y la forma de gobierno, ejerciendo además una influencia de sentido opuesto sobre la selección de dicha forma de gobierno.

PALABRAS CLAVE I Forma de gobierno, integración, control formal, control informal, características de las transacciones. 


\section{INTRODUCTION}

Strategic decision-making regarding the degree of integration of an activity has been analyzed from a transactional perspective through the link between integration and governance forms. Transaction Cost Economics (TCE), developed by Oliver Williamson (Williamson, 1989, 1991a), focuses on predicting the form of governance structure or the degree of integration by examining transaction characteristics (Dekker, 2004). The main transaction characteristics are the frequency of transactions, the uncertainty derived from asymmetric information, and the relation-specific investments that bind the parties and generate hold-up problems (Dekker, 2004; Eriksson \& Laan, 2007; Howell, Meade, \& O'Connor, 2010; Langfield-Smith \& Smith, 2003). These three variables have positive effects on the degree of integration. However, incorporating social aspects can mitigate or even change this effect. In fact, frequency (Langfield-Smith \& Smith, 2003), relationspecific investments (Faems, Janssens, Madhok, \& Van Looy, 2008; Goo \& Huang, 2008; Langfield-Smith \& Smith, 2003), and information sharing (Faems et al., 2008; Goo \& Huang, 2008; Langfield-Smith \& Smith, 2003) favor trust and informal controls, and these reduce the need for integrated forms.

Although these developments are described as a whole, TCE considers the transaction characteristics and the mechanism of control as different steps in the selection of the governance form (Dekker, 2004; Langfield-Smith \& Smith, 2003; Williamson, 1989). Reuver and Bouwman (2012) also highlighted the need to differentiate the economic institution of transaction (market, hierarchy, and hybrid form) and the method of organizing the action (formal and informal controls).

From these developments it can be theorized that frequency, information sharing, and relation-specific investments determine the form of governing an activity. But they do so through the mechanism that organizes the action - that is, through the combination of formal control (degree of hierarchy) and informal control (degree of formalization), because it is the combination of these features that determines the advisable degree of integration.

The importance of the simultaneous presence of formal and informal control is highlighted in the literature, which states that it can be achieved with the same degree of control through different forms of governance that arise from different combinations of formal and informal mechanisms. See, for example, the formal and informal hierarchy of Diefenbach and Sillince (2011), the shared-governance networks of Cristofoli, Markovic, and Meneguzzo (2014), the vertical network organization of Baudry and Chassagnon (2012), and the contributions of Christiansen and Neuhold (2012), and Calabrò and Mussolino (2013).
However, the majority of the academic literature focuses on justifying only partial relationships between these groups of variables. Thus, a number of studies was conducted on the selection of the governance form by examining transaction characteristics (Crandall, Eisenach, \& Litan, 2010; Howell et al., 2010; Neumann, 2010; Waterman \& Choi, 2011), the definition of the control structure based on the transaction characteristics (Ding, Dekker, \& Groot, 2013; Johansson \& Siverbo, 2011; Meer-Kooistra \& Vosselman, 2000) and the influence of actionorganizing mechanisms on relationship outcomes (Reuver, 2011; Reuver \& Bouwman, 2012; Eriksson \& Laan, 2007; Langfield-Smith, 2008; Langfield-Smith \& Smith, 2003; Şengün \& Wasti, 2011).

There are few studies on the interactions between transaction characteristics, action-organizing mechanism and governance forms. These interactions were only partially approached from a relational perspective by Goo and Huang (2008) and through case study by Dekker (2004). Williamson (1991b) argues for the need to study strategizing, considering power arguments and the institutional environment in make-orbuy decisions. Also, Ménard (2004) highlights the influence of the institutional environment on the choice of a specific mode of hybrid form and proposes a typology of hybrid forms and the possible coexistence of different levels of integration; tighter coordination and trust are crucial to deal with the specificities and uncertainty involved in hybrid forms. And Christiansen and Neuhold (2012, p. 12) highlight that the real issue "concerns the identification of the conditions under which informal governance is helpful or even essential to the achievement of better outcomes"

Thus, this paper aims to analyze whether the set of mechanisms used to organize the action have any effects on the influence that the transaction characteristics have over selection of the governance form, or whether there is no such an effect and the degree of integration of the governance form is directly determined by the frequency, information sharing, and relationspecific investment factors (as has been proposed in TCE).

To achieve this purpose, the next sections address the theoretical background of hierarchical integration and governance forms and explain the research design. The following sections present the main results and the discussion of results. Finally, the last one presents conclusions, gaps, and indications for future research.

\section{THEORETICAL BACKGROUND AND HYPOTHESES}

From a transactional perspective, different forms of governance have distinct attributes that cannot be replicated in other structures and make each of them the most efficient form for a 
specific situation (Williamson, 1996). This perspective argues that the main differences between modes of governance refer to the ability to manage specific aspects. Thus, hierarchies have better attributes of information and adaptation than hybrid forms and markets (Crocker, 1983; Williamson, 1991a).

Information advantages are enhanced by audit superiority (Crocker, 1983) and by greater simplicity when there are codification systems that can increase communicative efficiency and give stability to operations (Rosen, 1996). Adaptive superiority is enhanced by the subordination of individual interests to the maximization of a common interest (Imai \& Itami, 1984) while promoting both workforce motivation (Simon, 1991) and the specialization of resources (Demsetz, 1988, 1995; Williamson, 1989, 1993); a firm can develop relation-specific investments without an increase in hold-up problems by fostering its own specific internal morality and originating relationships of institutional and personal trust (Masten, 1984; Ouchi, 1980; Ouchi \& Price, 1993).

It has been said that the control derived from hierarchical relationships is the main generator of differences between the forms of governance because it facilitates a more efficient conflict management (Palay, 1984) and increased coordination. Thus, integrated forms are associated with control over decisions (Baker, Gibbons, \& Murphy, 2002; Mahoney, 1992; Rosen, 1996). Where describing every right and obligation in detail for every conceivable future situation is too costly, the authority relation arises to avoid conflicts over the use of assets (Foss \& Foss, 2002).

While authority is associated with hierarchies, it is not enough to define a hierarchical governance form. The hierarchical principle of authority can also be present in cooperative governance forms near hierarchies such us joint ventures (Rialp \& Salas, 2002). Also, contracts can simulate hierarchical relations (Stinchcombe, 1985) and legally bind, enforce, and allow the control of activities (Reuver, 2011).

On the other hand, some authors argue that ownership is an essential variable as a source of rights associated with vertical integration (Hart, 1996). Legal ownership over assets transfers specific and residual rights to the owner. Residual rights are those rights that are not specified in contracts and allow a more efficient management of future situations (Foss \& Foss, 2002; Hart, 1996; Rialp \& Salas, 2002). Ownership can help a firm to adopt the governance form with the lowest cost (Howell et al., 2010). However, the owner can transfer or delegate the use of assets (Foss \& Foss, 2002); thus, while ownership favors control over decisions, ownership and control over decisions can be simultaneously present (hierarchy) or not (cooperation and market).

Therefore, property favors hierarchy but it does not determine hierarchy; also, property rights (understood as the hierarchical control over decisions and authority) are related with hierarchies but they are not sufficient to define a hierarchical governance form. Property and control can combine in different ways to shape different governance forms (Piesse, Strange, \& Toonsi, 2012). The simultaneous presence of property rights and single proprietorship are necessary to achieve the maximum degree of integration associated with a hierarchical governance form.

Hierarchy implies authority and a reallocation of property rights (Rialp \& Salas, 2002), i.e., the simultaneous presence of control over decisions and ownership (Coase, 1996; Lyons, 1994; Masten, Meehan, \& Snyder, 1989; Perry, 1989); this idea is associated with formal control (Fryxell, Dooley, \& Vryza, 2002; Miller, 2011). The degree of hierarchical governance decreases alongside the reduction of property rights and ownership; the intermediate points are hybrid forms, and the market is present when there is an absence of property rights and ownership.

Therefore, Hypotheses 1 and 2 are formulated as follows:

$\mathrm{H} 1$ : Formal control has a positive relation with the adoption of hierarchical governance forms.

$\mathrm{H}$ 2: Ownership has a positive influence on property rights.

Although TCE points out the existence of hybrid forms, the informal or social control involved in these forms is not well recognized by TCE theory (Srivastava \& Teo, 2012). The dichotomy market-hierarchy based on ownership and property rights is only associated with formal controls (Fryxell et al., 2002; Miller, 2011). However, the informal control based on common values and norms that often exists intangibly (Fryxell et al., 2002; Şengün \& Wasti, 2009) is essential in hybrid forms because informal control generates trust and commitment and reduces the need for formalization (Calabrò \& Mussolino, 2013; Eriksson \& Laan, 2007).

Informal control replaces explicit rules and regulations and promotes trust; trust and informal control are always co-present (Khodyakov, 2007; Şengün \& Wasti, 2009). The overuse of formal controls decreases trust (Smets, Oorschot, \& Langerak, 2013), and trust reduces the need to use formal control mechanisms (Dekker, 2004; Meer-Kooistra \& Vosselman, 2000). The benefits of this negative relationship between trust and formal control have been highlighted by numerous organizational scholars (Şengün \& Wasti, 2011).

Reuver (2011) and Reuver and Bouwman (2012) highlighted the relevance of informal control and trust as mechanisms of governance that generate a third and different way of governance at the same level of market and hierarchy. At the same time, they argue that these mechanisms of governance can be used in combination by organizations; they may partially overlap to configure particular ways of governance forms. Langfield-Smith 
and Smith (2003) affirmed that informal control is present in every organization simultaneously with formal, explicit controls, whether as outcome controls (market) or behavior controls (hierarchy); and Tessier and Otley (2012) propose that social and technical controls are part of all the various control systems of an organization. Also, Inauen, Osterloh, Frey, and Homberg, (2014) state that management control systems can be seen as packages, i.e., they relate to contingency variables depending on the balance between different types of control systems. Formal and informal control are complementary mechanisms (Calabrò \& Mussolino, 2013) and firms adapt their control structure to deal with contingency characteristics (Jokipii, 2010).

Moreover, a positive relationship can be established between ownership and informal control and between property rights and informal control. The ownership of specific physical assets can indicate the existence of credible commitment and trust on the part of the owner (Dyer, 1997); a lower use of formal norms in favor of informal ones is then expected. With regard to property rights, a few studies suggest that hierarchical relationships weaken trust, so relationships with a high degree of authority and control originate lack of trust as formal control indicates, in this case, that the party is reluctant to take risks in the relationship (Mayer, Davis, \& Schoorman, 1995), and this should reflect in a lower tendency to secure the relationship's future continuity and in less informal control.

Taking into account the relationship between property rights, ownership, and trust, we propose Hypotheses 3, 4, and 5.

$\mathrm{H}_{3}$ : Informal control has a negative influence on the adoption of hierarchical governance forms.

H4: Ownership has a positive influence on informal control.

$\mathrm{H}_{5}$ : Property rights have a negative influence on informal control.

With regard to transaction characteristics, TCE highlights the frequency of transactions, the uncertainty derived from asymmetric information, and the relation-specific investments that bind the parties and lead to hold-up problems as the main factors to consider in integrating an activity (Dekker, 2004; Eriksson \& Laan, 2007; Howell et al., 2010; Langfield-Smith \& Smith, 2003).

Relational contracting takes into account the historical context in which the relationship occurs to explain the use of informal agreements and norms in the relationship (Miller, 2011). Thus, the frequency of relationships reduces the risk of opportunistic behavior (Hill, 1990). After repeated interaction and feedback, good results from previous trustful actions will improve the perceptions of trust and favor successive transactions without excessive formalization (Dyer, 1997; Langfield-Smith \& Smith, 2003; Mayer et al., 1995). Prior ties between partners enable the use of less formal governance arrangements (Dekker, 2008) and, in the long run, these will be more economical (Fryxell et al., 2002). In turn, Arruñada, Garicano, and Vázquez (2001) connected frequency to asymmetrical contractual clauses that reduce the risk of nonfulfillment. From this transactional perspective, Subramani and Venkatraman (2003) and Baudry and Chassagnon (2012) argued that transaction frequency can generate specificities which would increase the likelihood of integration of the activity. Williamson (1989) held that frequency is important for the recovery of costs with specialized governance structures. If frequency influences the adoption of hierarchical governance forms, then a positive relationship could be expected between frequency and property rights, and between frequency and ownership. Therefore, Hypotheses $6 \mathrm{a}, 6 \mathrm{~b}$ and $6 \mathrm{c}$ are formulated as follows:

H6a: The frequency of the relationship has a positive influence on informal control.

H6b: The frequency of the relationship has a positive influence on property rights.

H6c: The frequency of the relationship has a positive influence on ownership.

A second factor that reinforces informal control (Goo \& Huang, 2008; Langfield-Smith \& Smith, 2003) and reduces transaction costs is the exchange of information between contracting parties (Roy \& Dugal, 1998; Selnes, 1998). Clauß (2012) referred to this transfer of information as "openness", which reflects the willingness to share sensitive information. Information transfers, frequent meetings, and communications between contracting partners reduce information asymmetry, the probability of opportunistic behavior, and transaction costs. They indicate goodwill and reduce the need for formal control (Das \& Teng, 2001; Dyer, 1997).

On the other hand, from the transactional viewpoint, the longer the wait in information transfers, the better the integration to improve coordination (Caves \& Bradburd, 1988). The sharing of information can be best conducted by means a hierarchical governance form due to its better coordinating qualities. Thus, we propose that information sharing will favor ownership and property rights over the activity. Therefore, Hypotheses $7 \mathrm{a}, 7 \mathrm{~b}$, and $7 c$ are formulated as follows:

H7a: Information sharing has a positive influence on informal control.

H7b: Information sharing has a positive influence on property rights.

H7c: Information sharing has a positive influence on ownership. 
A third significant factor that works as an originator of informal control (Goo \& Huang, 2008; Langfield-Smith \& Smith, 2003) and as a reducer of transaction costs is relation-specific investment. A legal contract can minimize costs in short-term transactions, but self-obliging safeguards like relation-specific investments are more efficient if the exchange is expected to have a long duration (Dyer, 1997). Although they are assumed to have high initial costs (Sako, 1992), once created, their maintenance costs are relatively low. Successful mutual adaptation creates trust and credible commitments that reduce transaction costs, the need for authority, and the need for more integrated forms of governance (Baudry \& Chassagnon, 2012; Dyer, 1997). In relationships based on relation-specific investments, individuals show an increased tendency to adopt initiatives that may not have been explicitly agreed on but increase the value of the transaction. Once a high level of trust has been established, successive specialized investments will reinforce the trust and credibility of the commitment.

From the transactional perspective, traditional TCE connects protection from opportunistic behavior to the adoption of mechanisms of governance. The greater the assets' specificity, the closer the form of governance should be to integration. These more integrated structures protect the parties from transaction costs and the risks of opportunism (Lyons, 1994; Williamson, 1989, 1991a). Thus, relation-specific investments should lead to more property rights and ownership. Hypotheses $8 a, 8 b$, and $8 c$ are formulated as follows:

H8a: Relation-specific investments have a positive influence on informal control.

H8b: Relation-specific investments have a positive influence on property rights.

H8c: Relation-specific investments have a positive influence on ownership.

Frequency, information sharing, and relation-specific investments influence formal control (property rights and ownership) and informal control (lack of formalization), but their influence on the selection of the governance form are in opposition. Therefore, the total influence on the governance form can vary depending on the combination of property rights, ownership, and informal norms. We propose that these three variables act as mediating variables in the effect that frequency, information sharing, and relation-specific investments have on the selection of the form of governance; informal control has the opposite effect, acting as a substitute for hierarchical governance.

\section{RESEARCH DESIGN AND DEVELOPMENT}

Our field study analyzed telephone operators in the telecommunications industry in Spain (Europe). We chose this industry to test our hypotheses for three reasons. It is the service sector activity that has contributed most to investment and GDP in recent years (Spanish National Statistics Institute, www.ine.es), thus becoming the main driver of economic development in the country. Moreover, companies in this industry contribute significantly to the welfare of society and the quality of life of citizens, making this a strategic sector in Spain.

Secondly, there are no studies analyzing the determinants of vertical integration in this sector. The majority of the academic literature focuses on legal aspects of the regulations that should be designed to control the behavior of vertically integrated operators (Cave, 2006; Crandall et al., 2010; Howell et al., 2010; Waterman \& Choi, 2011). A few authors approach this topic from an economic perspective in analogous activities, like cable television (Waterman \& Choi, 2011; Yoo, 2002) or the electric power industry (Howell et al., 2010), and from the perspective of governance forms in the mobile service (Reuver \& Bouwman, 2012) and IT outsourcing industries (Goo \& Huang, 2008). There is some discussion concerning network neutrality, but a few aspects, like ISP integration into other activities, have received little academic attention (Waterman \& Choi, 2011).

Thirdly, because vertical integration is "the more natural and resilient industry structure" (Howell et al., 2010, p. 393), organizations tend to integrate vertically in order to solve failings in contracts derived from higher risk, asymmetric information, market power, and large investments. In Spain, more than 10 years after liberalization, the market is still strongly concentrated. Telefónica owns more than $50 \%$ of domestic market share, and the 4 main operators account for $90 \%$; these 4 operators come from initial European monopolists. Internet service providers (ISPs) are potential retail bottlenecks; if the market shares of the largest ISP providers become large enough, they could control consumers' access to other Internet services (Waterman \& Choi, 2011) and discriminate against upstream or downstream competitors (Crandall et al., 2010).

This suggests that high-sunk costs (investments in infrastructure inherent in the sector) (Crandall et al., 2010) continue to influence business dynamics, limiting the access of new entrants and therefore competition. Certain stages of the value chain can only be carried out by dominant operators, and this determines the power structures and levels of integration. Consequently, strategic decisions about the form of governance of each activity are limited, overriding informal control in interfirm relationships. 
This paper proposes that informal control is at the same level as the traditionally studied characteristics related with integration decisions (property rights and ownership), being an essential element in governance form decisions even in sectors with structural constraints.

Since this industry is highly concentrated according to the available data, we focused our study on Internet access providers with a market share higher than $1 \%$; these firms comprise $93 \%$ of users, $80 \%$ of total incomes (Comisión del Mercado de las Telecomunicaciones [CMT], 2011), and $90 \%$ of market share (Asociación para la Investigación de Medios de Comunicación [AIMC], 2012). To select the target population, we used data from the Spanish National Commission for Telecommunications (CMT, 2011) and the Media Research Association (AIMC, 2012). The information was collected by means of a questionnaire. Our data collection used the "key informant" methodology, which relies on a selected set of members to provide information about organizational characteristics (Goo \& Huang, 2008). Respondents must have positions like President, CIO/Vice President, Director/ Assistant Vice President, Operations Manager, or Contract Officer

Most governance studies focus on dyadic buyer-supplier relationships. Reuver and Bouwman (2012), in their analysis of value network, expanded the analysis to consider relationships with organizations that, according to the respondent's perception, are part of his organization's value network. However, that procedure seems inadequate to study the degree of integration of governance forms within an industry because a global assessment of the governance forms of the primary activities in that industry's value chain is then advised.

Cassiman and Sieber (2007), and Valor and Hess (2002) identified the following primary activities in the ISP industry's value chain: (1) user interface (user devices, applications and software, access technology, and services rights); (2) retail Internet access (retail-enabling technology, retail transit service, and enabling technology to connect with ISPs); (3) services (enabling technology to supply Internet services, services rights, and basic online services (mail, ftp, news, etc.)), advanced online services (hosting, gaming platforms, e-commerce platforms, etc.), and contents developing; (4) a core network (enabling technology to connect to the backbone, backbone transit service, and enabling technology to interchange); and (5) costumer care, infrastructure works, and hardware manufacturing.

Measuring all relationships separately using a complex instrument of measurement has been considered infeasible given respondents' workload (Varamaki \& Vesalainen, 2003) and the likelihood of nonresponse (Reuver \& Bouwman, 2012). Therefore, respondents were asked to answer all the questions for every primary activity in the industry value chain, but the measures were adapted to select observable variables.

Following TCE, the degree of integration of each activity was measured through the existing form of governance to manage that activity. Companies were asked to indicate the method of governance chosen for each activity, from five options: no relationship, buyer relationship, cooperation, group company, and in-house activity.

In the same way, following the transactional background, we selected observable measures according to the descriptions of the characteristics of transactions (Clauß, 2012; Dekker, 2004; Eriksson \& Laan, 2007; Howell et al., 2010; Langfield-Smith \& Smith, 2003) and according to the meanings of the mechanisms that organize action (Reuver \& Bouwman, 2012). The variables were codified through a 1-5 Likert scale (Exhibit 1).

\section{Exhibit 1. Variables}

\begin{tabular}{|c|c|c|}
\hline Variable & Name & Description \\
\hline Frequency & frequency & How often interactions take place \\
\hline Information sharing & openness & $\begin{array}{l}\text { To what degree a partner acquaints the other with its real being. How openly information } \\
\text { are shared }\end{array}$ \\
\hline $\begin{array}{l}\text { Relation-specific } \\
\text { investments }\end{array}$ & specificity & Rate of specific assets involved in the activity which were created during the relationship \\
\hline Informal control & Informal & $\begin{array}{l}\text { How many aspects are specified in writing. What is the reason for, and the content of, the } \\
\text { relationship }\end{array}$ \\
\hline Property rights & prop._rights & Level of control that the company has over performing of each activity \\
\hline Ownership & ownership & Proportion of ownership the company has on the assets required for each activity \\
\hline
\end{tabular}


The target population consists of 512 cases, which were obtained by multiplying the number of companies obtained from the above mentioned respondents ( 32 companies) by the number of primary activities in the industry's value chain (16 tasks). The size of the sample was 325 cases, obtaining a sample error of $3.29 \%$ at a level of confidence of $95 \%$. The firms in the sample comprise $72 \%$ of users, $55 \%$ of total incomes, and $62 \%$ of market share (AIMC, 2012)

The hypotheses were contrasted using Structural Equation Modelling (SEM). The SEM approach is recommended by several authors to evaluate effects of mediation (Cheung \& Lau, 2007; lacobucci, Saldanha, \& Deng, 2007). We employed path analysis as the variables should not be grouped due to the need for overidentification; Sharma (2002) accepted this approach because it is a less demanding method for known parameters.

To examine the mediated effect of informal norms, property rights, and ownership, we followed the strategy suggested by Holmbeck (1997). Assuming that frequency, information sharing, and relation-specific investments are the predictor variables (A), informal norms, property rights, and ownership are the mediator variables (B), and the governance form is the outcome variable (C),
[...] one would assess the fit of the direct effect (A $\rightarrow C$ ) model [and] assess the fit of the $A \rightarrow B \rightarrow C$ model under two conditions: (a) when the $A \rightarrow C$ path is constrained to zero, and (b) when the $A$ $\rightarrow C$ path is not constrained. One then examines whether the second model provides a significant improvement in fit over the first model. [...]. If there is a mediational effect, the addition of the $A \rightarrow C$ path to the constrained model should not improve the fit. (Holmbeck, 1997, p. 602)

The maximum verisimilitude estimation method was used because it is coherent, not skewed, efficient, does not vary with scale type, and is appropriate for large sample sizes (Mangin \& Mallou, 2003). A bootstrapping technique was used because data did not show a multivariate normal distribution (Hair, Anderson, Tatham, R.L., \& Black., 1999). To re-specify the model and obtain a parsimonious model, our criterion was to suppress causal relationships with a critical ratio smaller than $1.96(p>0.05)$.

\section{RESULTS}

The following re-specified model was obtained (Figure 1, Table 1):

Figure 1. Re-specified model of telephone operators

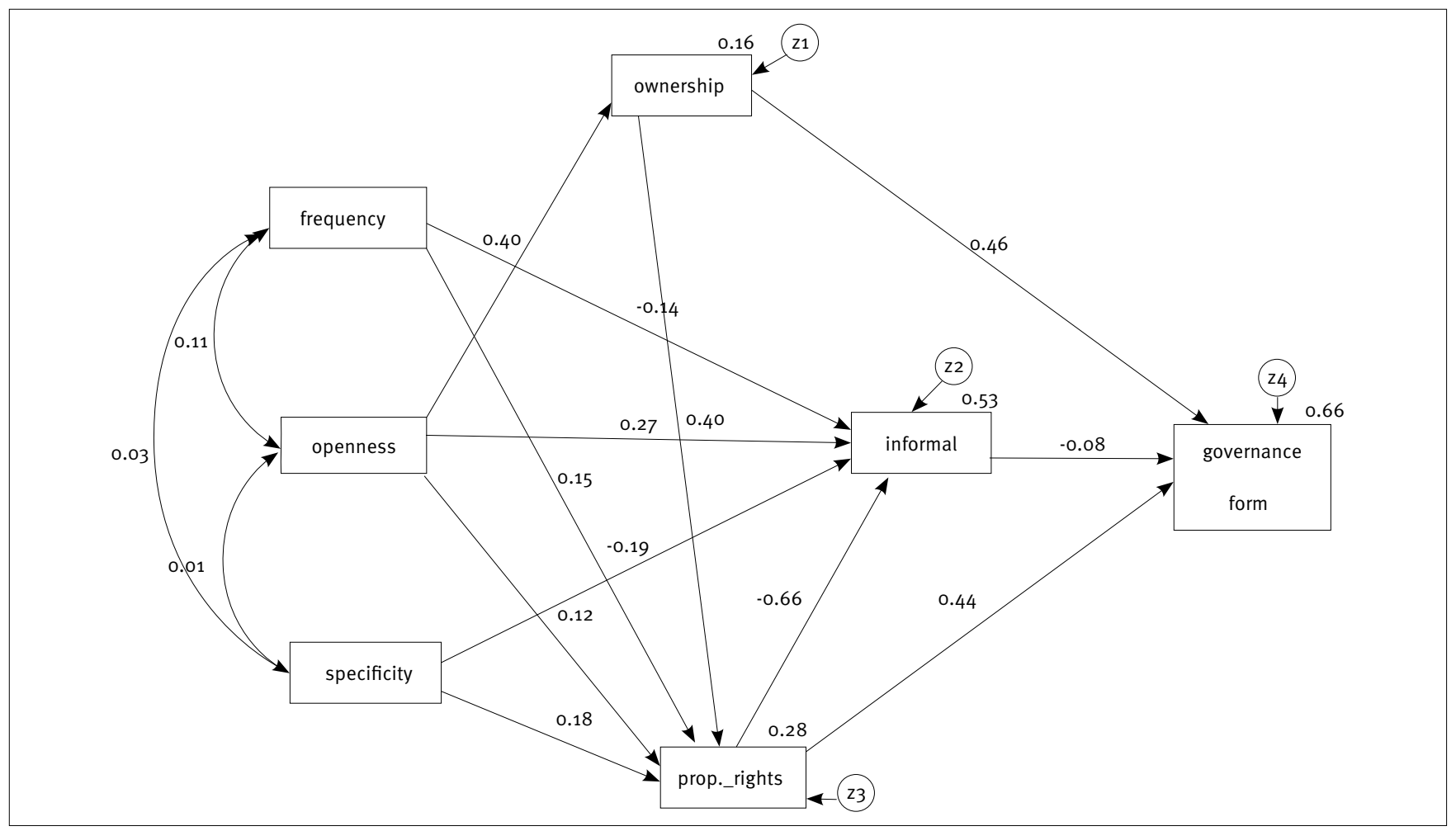


Table 1. Constrained model regression weights and squared multiple correlations

\begin{tabular}{|c|c|c|c|c|c|}
\hline & & & \multicolumn{3}{|c|}{ Regression weights } \\
\hline ownership & $<-$ & openness & 0.490 & 7.069 & 0.404 \\
\hline prop._rights & $<-$ & ownership & 0.250 & 6.881 & 0.398 \\
\hline prop._rights & $<-$ & openness & 0.095 & 2.145 & 0.125 \\
\hline informal & $<-$ & prop._rights & -0.774 & -14.082 & -0.657 \\
\hline informal & $<-$ & openness & 0.240 & 5.895 & 0.267 \\
\hline informal & $<-$ & frequency & -0.338 & -3.284 & -0.144 \\
\hline informal & $<-$ & specificity & -0.158 & -4.287 & -0.188 \\
\hline \multicolumn{2}{|c|}{ Explicated variables } & $\begin{array}{l}\text { Squared Multiple } \\
\text { Correlations }\end{array}$ & Explicated variables & \multicolumn{2}{|c|}{$\begin{array}{l}\text { Squared Multiple } \\
\text { Correlations }\end{array}$} \\
\hline \multirow{2}{*}{\multicolumn{2}{|c|}{$\begin{array}{l}\text { prop._rights } \\
\text { ownership }\end{array}$}} & 0.283 & \multirow{2}{*}{$\begin{array}{l}\text { informal } \\
\text { governance form }\end{array}$} & \multicolumn{2}{|l|}{0.526} \\
\hline & & 0.163 & & \multicolumn{2}{|l|}{0.657} \\
\hline
\end{tabular}

Positive variances, high multiple correlations (Table 1), and indexes within advisable ranges (Table 1) confirm the goodness of fit for the re-specified model. Residuals and modification indices do not suggest additional paths between the endogenous variables in the model. The difference between the two model chi-squares confirms the lack of significance of the direct path and, therefore, the mediational effect (Table 2).

Table 2. Models fit summary and difference between the two models' chi-squares

\begin{tabular}{|c|c|c|c|}
\hline Recommended values* & \multicolumn{3}{|c|}{ Models fit summary } \\
\hline \multicolumn{4}{|l|}{ Absolute measures } \\
\hline$x^{2}(p \geq 0.05)$ & $3.610(0.307)$ & $1.756(0.625)$ & $6.473(0.372)$ \\
\hline RMSEA $£ 0.08$ & 0.028 & 0.000 & 0.018 \\
\hline \multicolumn{4}{|l|}{ Incremental measures } \\
\hline $\mathrm{RFI} \approx 1$ & 0.789 & 0.980 & 0.963 \\
\hline $\mathrm{IFI} \approx 1$ & 0.980 & 1.002 & 0.999 \\
\hline $\mathrm{TLI} \geq 0,9$ & 0.957 & 1.015 & 0.997 \\
\hline $\mathrm{CFI} \geq 0,95$ & 0.978 & 1.000 & 0.999 \\
\hline \multicolumn{4}{|l|}{ Measure of parsimony } \\
\hline Constrained model ${ }^{\star \star}$ & 3 & 4.717 & 0.194 \\
\hline
\end{tabular}

* (Cai, Goh, Souza, \& Li, 2013; Hair et al., 1999; Mangin \& Mallou, 2003; Xie \& Peng, 2011)

** $p>0.05 \cdots$ - *the constrained model is accepted

The acceptance and rejection of the hypotheses are shown in Exhibit 2. 


\section{Exhibit 2. Acceptance and rejection of hypotheses}

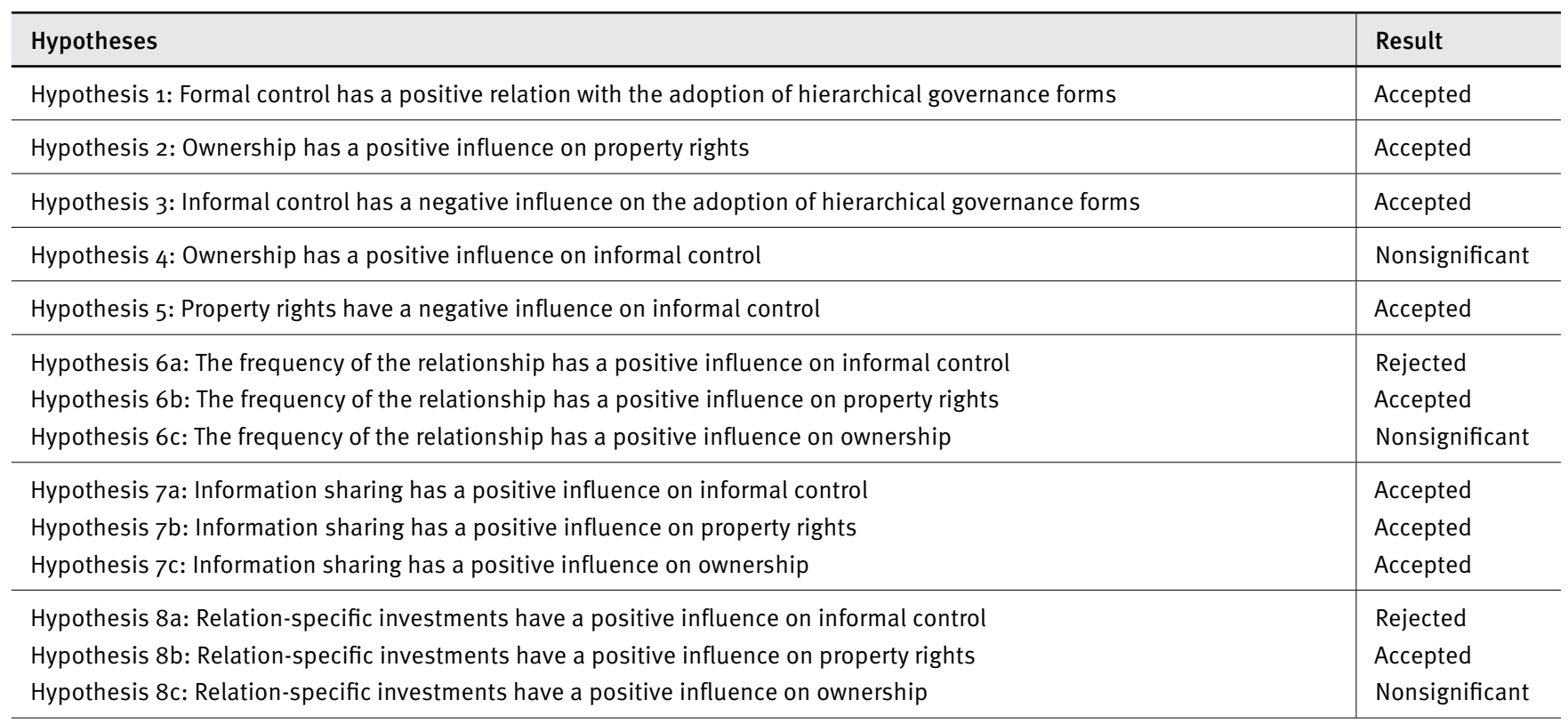

\section{DISCUSSION}

With regard to the effects of the action-organizing mechanisms on the degree of hierarchical governance, Hypotheses 1, 2, 3, and 5 are accepted. Therefore, results confirm that each governance form has distinctive properties and that its adoption depends on the combination of formal (ownership and property rights) and informal norms.

So the positive relationship between ownership and the degree of hierarchical governance is accepted (Jeuland \& Shugan, 1983). Therefore, ownership appears to impact the adoption of integrated forms of governance, with advantages due to its residual rights of control. Property rights are also considered to be determinants of vertical integration (Baker et al., 2002; Mahoney, 1992; Rosen, 1996); authority-based control over tasks fosters coordination, adaptation, and communication between individuals (Subramani \& Venkatraman, 2003) (Hypothesis 1).

Hypothesis 3 is also significant for the analyzed telephone operators. Thus, the evidence seems to accept the negative influence of informal controls on vertical integration (Miller, 2011; Reuver, 2011; Reuver \& Bouwman, 2012). These results suggest that this kind of control can reduce the need for integration. Informal norms by themselves seem to deliver some advantages of information and coordination originally attributed to hierarchical forms. The degree of integration is mediated by informal norms that exert an attenuating effect on integration, thus counteracting the effect of the other variables. Therefore, we confirm the relevance of informal mechanisms on the selection of the governance form at the same level as market and hierarchy but with the opposite effect (Reuver, 2011; Reuver \& Bouwman, 2012), and the presence of informal and formal controls simultaneously (Langfield-Smith \& Smith, 2003).

With regard to the interrelations between the actionorganizing mechanisms (both formal and informal) all hypotheses are accepted (i.e., Hypotheses 2 and 5) except for the relation between ownership and the lack of formalization (Hypothesis 4). The acceptance of Hypothesis 2 lends support to the property literature advocating the allocation of residual rights as a result of asset ownership (Howell et al., 2010). Hypothesis 5 was accepted as well. Thus, the use of hierarchical rules appears to have a negative influence on informal control, as measured through the contractual structure (Mayer, et al., 1995; Meer-Kooistra \& Vosselman, 2000; Şengün \& Wasti, 2011).

However, Hypothesis 4 is nonsignificant, so the proposition about the positive relationship between ownership and informal norms (Dyer, 1997) cannot be accepted. The telephone operators showed a nonsignificant sign, which agrees with the existence of specific physical assets and their protection through ownership, according to the TCE. This result may be due to operators' large investment needs and their significant effort to define tasks, procedures, and relationships in a new technological context. Considering the influence of frequency, information sharing, and relation-specific investments, our exogenous variables will allow us to go deeper in this explanation.

With regard to the influence of frequency, information sharing, and relation-specific investments, the majority of the relationships were confirmed, indicating that transaction 
characteristics affect the choice of governance form through its main action-organizing mechanisms. Results seem to confirm the mediated effect of formal and informal norms on the degree of hierarchical governance. A relationship cannot be established between frequency, information sharing, and relation-specific investments in terms of integration without evaluating the effects of these variables on property rights, ownership, and informal norms because the total effect may vary based on the partial effects from each of these variables.

Concerning the transmission of information, all hypotheses are accepted, so the results suggest that it indirectly influences the degree of hierarchical governance. Thus, the positive influence of information sharing on informal norms (Goo \& Huang, 2008; Langfield-Smith \& Smith, 2003) is corroborated (Hypothesis 7a); this relationship enhances the negative effect of informal norms on hierarchical governance. However, the acceptance of the positive influence of information sharing on property rights (Hypothesis 7b) and ownership (Hypothesis 7c) based on TCE (Dekker, 2004; Eriksson \& Laan, 2007; Howell et al., 2010) enhances the increase in the degree of hierarchical governance. Formal and informal mechanisms of organization then become parallel and opposite.

With regard to the frequency and relation-specific investments, only Hypotheses $6 \mathrm{~b}$ and $8 \mathrm{~b}$ were accepted (positive relationship with authority). As we expected, the evidence seems to accept a positive influence on property rights, according to TCE (Dekker, 2004; Eriksson \& Laan, 2007; Howell et al., 2010). However, the relationships between these variables and ownership are nonsignificant (Hypotheses $6 \mathrm{c}$ and $8 \mathrm{c}$ ), while with informal norms they are rejected, showing negative signs (Hypotheses 6a and 8a).

Positive influences on property rights combined with the lack of significance of ownership indicate that companies perceive control over all their tasks to be indispensable, but ownership is determined by other factors. This result demonstrates that in the telecommunications industry, which contains high sunk costs (Crandall et al., 2010), the investment of specific assets is not a subject that firms can decide on without constraints. The experimental empirical evidence, i.e., that the sunk cost bias influences the choice of governance structure (Miller, 2011), was supported. So despite the liberalizing regulations in recent years, infrastructure barriers to entry continue to force new entrants towards costly investments.

With regard to informal control, we found negative signs between frequency and informal norms (Hypothesis 6a) and between relation-specific investments and informal norms (Hypothesis 8a), unlike the positive one proposed in the academic literature (Goo \& Huang, 2008; Langfield-Smith \& Smith, 2003). There is no support for a reduction in the need to protect specific investments in favor of the use of formal norms (Lyons, 1994; Subramani \& Venkatraman, 2003).

These negative relationships with informal norms could be explained by a greater difficulty to decide on the correct moves in the telecommunications industry, which is characterized by new, complex technology, complexity of activities, and specific human resources (Crandall et al., 2010). In this case, it is necessary to use formal action-organizing mechanisms to prevent performance failure. Thus, companies will create technical specifications and procedures to ensure the acquisition and possession of skills related to each activity. In the short term, this reduces trust and formalization, but in the long term, formal governance structures could develop trusting relationships because the creation of mutual transparency creates a less informal governance structure (Dekker, 2004).

The total effect of frequency and relation-specific investments on the degree of hierarchical governance is positive. Reduction of transaction costs by long-established ties because of these two factors (Dyer, 1997) is difficult to support in this sector.

These results confirm the arguments presented earlier on the importance of property rights and hierarchical governance. In an industry like telecommunications, with its structural particularities, an authority-like mechanism to organize actions and its influence on the adoption of hierarchic governance forms are important. Moreover, the ownership of infrastructures in this sector limits free competition and confirms that integrated governance forms are the natural industry structure.

Finally, the result indicates the need to consider simultaneously formal and informal controls to select the governance form. On the one hand, frequency and relation-specific investments highlight the presence of formalization instead of informal norms, reinforcing the idea of preference for hierarchical governance. On the other hand, the importance of informal norms to manage interfirm relationships and balance the effects of formal control on the degree of hierarchy is expressed in the transmission of information. Transparency between agents favors symmetry and reduces complexity, allowing a less formalized relationship and, therefore, a less hierarchical governance form.

\section{CONCLUSIONS, LIMITATIONS, AND INDICATIONS FOR FUTURE RESEARCH}

The present analysis supports the proposition that actionorganizing mechanisms (i.e., formal and informal controls) mediate the effect of the transaction characteristics (frequency, information sharing, relation-specific investments) on the degree of hierarchical governance. According to TCE, transaction 
characteristics and action-organizing mechanisms are different steps in the selection of the governance form (Dekker, 2004; Langfield-Smith \& Smith, 2003; Williamson, 1989) and the interaction between these sets of variables is what determines the governance form.

Formal and informal mechanisms are simultaneously present. Thus, to select the degree of hierarchical governance, firms use property rights in combination with ownership, but they consider the existence of informal norms with opposite effects to those of property rights and ownership on hierarchical governance. Informal norms can act as a substitute for hierarchy in defining the governance form.

With regard to formal mechanisms, in the telecommunications industry, both the authority-like mechanism that organizes action and the influence of that mechanism on the adoption of hierarchic governance forms are important. Moreover, the costly infrastructures that characterize this industry limits free competition and makes government regulations insufficient; telephone operators are forced to integrate the entire value chain. This fact and the complexity of activities lead these operators to increase contractual formalization instead of attaching greater importance to the generation of trust and the strengthening of relationships.

As for informal mechanisms, the variable information shows a positive relationship with informal norms and, consequently, a reduction in the degree of hierarchical governance. Therefore, informal control is a factor that has to be taken into account in managing the forms of governance, even in sectors with structural constraints like the telecommunications industry.

Although all results seem significant, the present study shows a first test of these relationships, so further research is required to corroborate our findings. In this respect, one limitation arises from the fact that each variable in the model was measured through observable variables, implying the risk of representation of some of the concepts.

Future research should study these relationships from a dynamic perspective to confirm the findings of this study regarding the effect of past experience in defining the governance form, and to evaluate the period of time necessary to acquire or change past experiences. A formal governance structure can guarantee the stability and continuity of a relationship in the future, i.e., formal control mechanisms can act as generators of trust (Das \& Teng, 2001; Dekker, 2004; Vázquez, Iglesias, \& Alvarez-González, 2005). Therefore, certain forms of governance can change past experiences and drive the selection of a new combination of action-organizing mechanisms and the evolution of the governance form.

\section{REFERENCES}

Arruñada, B., Garicano, L., \& Vázquez, L. (2001). Contractual allocation of decision rights and incentives: The case of automobile distribution. Journal of Law, Economics, and Organization, 17(1), 257-284. doi:10.1093/jleo/17.1.257

Asociación para la Investigación de Medios de Comunicación. (2012). Navegantes en la red: $14^{a}$ encuesta AIMC a usuarios de internet 2011. Madrid, España: Asociación para la Investigación de Medios de Comunicación.

Baker, G., Gibbons, R., \& Murphy, K. J. (2002). Relational contracts and the theory of the firm. Quarterly Journal of Economics, 117(1), 39-84. doi:10.1162/003355302753399445

Baudry, B., \& Chassagnon, V. (2012). The vertical network organization as a specific governance structure: What are the challenges for incomplete contracts theories and what are the theoretical implications for the boundaries of the (hub-) firm? Journal of Management \& Governance, 16(2), 285-303. doi:10.1007/s10997-010-9148-z

Cai, S., Goh, M., Souza, R. de, \& Li, G. (2013). Knowledge sharing in collaborative supply chains: Twin effects of trust and power. International Journal of Production Research, 51(7), 2060-2076. doi:10.1080/00 207543.2012.701780

Calabrò, A., \& Mussolino, D. (2013). How do boards of directors contribute to family SME export intensity? The role of formal and informal governance mechanisms. Journal of Management \& Governance, 17(2), 363-403. doi:10.1007/s10997-011-9180-7

Cassiman, B., \& Sieber, S. (2007). The impact of the internet on market structure. In A. J. Salazar \& S. Sawyer (Eds.). Handbook of information technology in organizations and electronic markets (pp. 299-322). Singapore: World Scientific Publishing Co. Pte. Ltd.

Cave, M. (2006). Six degrees of separation: Operational separation as a remedy in European telecommunications regulation. Communications \& Strategies, 64(4), 84-104.

Caves, R. E., \& Bradburd, R. M. (1988). The empirical determinants of vertical integration. Journal of Economic Behavior \& Organization, 9(3), 265-279. doi:10.1016/0167-2681(88)90037-6

Cheung, G. W., \& Lau, R. S. (2007). Testing mediation and suppression effects of latent variables: Bootstrapping with structural equation models. Organizational Research Methods, 11(2), 296325. doi: $10.1177 / 1094428107300343$

Christiansen, T., \& Neuhold, C. (2012). International handbook on informal governance. [s.l.] Edward Elgar Publishing.

Clauß, T. (2012). The influence of the type of relationship on the generation of innovations in buyer-supplier collaborations. Creativity and Innovation Management, 21(4), 388-411. doi:10.1111/j.14678691.2012.00651.x

Coase, R. H. (1996). La naturaleza de la empresa. In O. E. Williamson \& S. G. Winter (Eds.). La naturaleza económica de la empresa (pp. 29-103). México D. F., Mexico: Fondo de Cultura Económica.

Comisión del Mercado de las Telecomunicaciones. (2011). Informe económico sectorial: Informe anual 2011. Madrid, España: Comisión del Mercado de las Telecomunicaciones.

Crandall, R. W., Eisenach, J. A., \& Litan, R. E. (2010). Vertical separation of telecommunciations networks: Evidence from five countries. Federal Communications Law Journal, 62(3), 493-540. 
Cristofoli, D., Markovic, J., \& Meneguzzo, M. (2014). Governance, management and performance in public networks: How to be successful in shared-governance networks. Journal of Management \& Governance, 18(1), 77-93. doi:10.1007/s10997-012-9237-2

Crocker, K. J. (1983). Vertical integration and the strategic use of private information. The Bell Journal of Economics, 14(1), 236-248. doi:10.2307/3003550

Das, T. K., \& Teng, B.-S. (2001). Trust, control, and risk in strategic alliances: An integrated framework. Organization Studies, 22(2), 251283. doi:10.1177/0170840601222004

Dekker, H. C. (2004). Control of inter-organizational relationships: Evidence on appropriation concerns and coordination requirements. Accounting, Organizations \& Society, 29(1), 27-49. doi:10.1016/S03613682(02)00056-9

Dekker, H. C. (2008). Partner selection and governance design in interfirm relationships. Accounting, Organizations and Society, 33(7-8), 915-941. doi:10.1016/j.aos.2007.02.002

Demsetz, H. (1988). Ownership, control and the firm: The organization of economic activity. Oxford, United Kingdom: Basil Blackwell.

Demsetz, H. (1995). The economics of the business firm: Seven critical commentaries. Cambridge, United Kingdom: Cambridge University Press.

Diefenbach, T., \& Sillince, J. A. A. (2011). Formal and informal hierarchy in different types of organization. Organization Studies, 32(11), 15151537. doi:10.1177/0170840611421254

Ding, R., Dekker, H. C., \& Groot, T. (2013, June). Risk, partner selection and contractual control in interfirm relationships. Management Accounting Research, 24(2), 140-155. doi:10.1016/j.mar.2013.04.007

Dyer, J. (1997). Effective interfirm collaboration: How firms minimize transaction costs and maximize transaction value. Strategic Management Journal, 18(7), 535-556.

Eriksson, P. E., \& Laan, A. (2007). Procurement effects on trust and control in client-contractor relationships. Engineering Construction \& Architectural Management, 14(4), 387-399. doi:10.1108/09699980710760694

Faems, D., Janssens, M., Madhok, A., \& Van Looy, B. (2008). Toward an integrative perspective on alliance governance: Connecting contract design, trust dynamics, and contract application. Academy of Management Journal, 51(6), 1053-1078.

Foss, K., \& Foss, N. J. (2002). The knowledge-based approach and organizational economics: How much do they really differ? And how does it matter? In N. J. Foss \& V. Mahnke (Eds.). Competence, governance, and entrepreneurship: Advances in economic strategy research (pp. 55-79). [s.l.] Oxford University Press.

Fryxell, G. E., Dooley, R. S., \& Vryza, M. (2002). After the ink dries: The interaction of trust and control in US-based international joint ventures. Journal of Management Studies, 39(6), 865-886. doi:10.1111/14676486.00315

Goo, J., \& Huang, C. D. (2008). Facilitating relational governance through service level agreements in IT outsourcing: An application of the commitment-trust theory. Decision Support Systems, 46(1), 216 232. doi:10.1016/j.dss.2008.06.005

Hair, J. F., Anderson, R. E., Tatham, R. L., Black, W. C. (1999). Análisis de datos multivariante. Upper Saddle River, USA: Prentice Hall.

Hart, O. D. (1996). Los contratos incompletos y la teoría de la empresa. In O. E. Williamson \& S. G. Winter (Eds.). La naturaleza de la empresa: Orígenes, evolución y desarrollo (pp. 192-219). México D.F., Mexico: Fondo de Cultura Económica.
Hill, C. W. (1990). Cooperation, opportunism, and the invisible hand: Implications for transaction cost theory. Academy of Management Review, 15(3), 500-513. doi:10.5465/amr.1990.4309111

Holmbeck, G. N. (1997). Toward terminological, conceptual, and statistical clarity in the study of mediators and moderators: Examples from the child-clinical and pediatric psychology literatures. Journal of Consulting and Clinical Psychology, 65(4), 599-610.

Howell, B., Meade, R., \& O'Connor, S. (2010). Structural separation versus vertical integration: Lessons for telecommunications from electricity reforms. Telecommunications Policy, 34(7), 392-403. doi:10.1016/j.telpol.2010.05.003

Iacobucci, D., Saldanha, N., \& Deng, X. (2007). A meditation on mediation: Evidence that structural equations models perform better than regressions. Journal of Consumer Psychology, 17(2), 139-153. doi:10.1016/S1057-7408(07)70020-7

Imai, K., \& Itami, H. (1984). Interpenetration of organization and market: Japan's firm and market in comparison with the US. International Journal of Industrial Organization, 2(4), 285-310. doi:10.1016/01677187(84)90001-8

Inauen, E, Osterloh, M., Frey, B. S., \& Homberg, F. (2014). How a multiple orientation of control reduces governance failures: A focus on monastic auditing. Journal of Management \& Governance, 19(4), 763796. doi:10.1007/s10997-014-9292-y

Jeuland, A. P., \& Shugan, S. M. (1983). Managing channel profits. Marketing Science, 2(3), 239-272. doi:10.1287/mksc.1070.0332

Johansson, T., \& Siverbo, S. (2011). Governing cooperation hazards of outsourced municipal low contractibility transactions: An exploratory configuration approach. Management Accounting Research, 22(4), 292-312. doi:10.1016/j.mar.2011.01.001

Jokipii, A. (2010). Determinants and consequences of internal control in firms: A contingency theory based analysis. Journal of Management \& Governance, 14(2), 115-144. doi:10.1007/s10997-009-9085-X

Khodyakov, D. M. (2007). The complexity of trust-control relationships in creative organizations: Insights from a qualitative analysis of a conductorless orchestra. Social Forces, 86(1), 1-22. doi:10.1353/ sof. 2007.0100

Langfield-Smith, K. (2008). The relations between transactional characteristics, trust and risk in the start-up phase of a collaborative alliance. Management Accounting Research, Management Control Systems as a Package, 19(4), 344-364. doi:10.1016/j.mar.2008.09.001

Langfield-Smith, K., \& Smith, D. (2003). Management control systems and trust in outsourcing relationships. Management Accounting Research, 14(3), 281-307. doi:10.1016/S1044-5005(03)00046-5

Lyons, B. R. (1994). Contracts and specific investment: An empirical test of transaction cost theory. Journal of Economics \& Management Strategy, 3(2), 257-278. doi:10.1111/j.1430-9134.1994.00257.x

Mahoney, J. T. (1992). The choice of organizational form: Vertical financial ownership versus other methods of vertical integration. Strategic Management Journal, 13(8), 559-584. doi:10.1002/smj.4250130802

Mangin, J. P. L., \& Mallou, J. V. (2003). Análisis multivariable para las ciencias sociales. Madrid, España: Prentice Hall.

Masten, S. E. (1984). The organization of production: Evidence from the aerospace industry. Journal of Law and Economics, 27(2), 403-417.

Masten, S. E., Meehan, J. W., Jr., \& Snyder, E. A. (1989). Vertical integration in the US auto industry: A note on the influence of transaction specific assets. Journal of Economic Behavior \& Organization, 12(2), 265-273. doi:10.1016/0167-2681(89)90059-0 
Mayer, R. C., Davis, J. H., \& Schoorman, F. D. (1995). An integrative model of organizational trust. Academy of Management Review, 20(3), 709-734.

Meer-Kooistra, J. Van Der, \& Vosselman, E. G. (2000). Management control of interfirm transactional relationships: The case of industrial renovation and maintenance. Accounting, Organizations and Society, 25(1), 51-77. doi:10.1016/So361-3682(99)00021-5

Ménard, C. (2004). The economics of hybrid organizations. Journal of Institutional and Theoretical Economics, 160(3), 345-376. doi:10.1628/0932456041960605

Miller, F. (2011). Using formal and informal controls to limit opportunism: Review and classification of remedies to hold-ups. Journal of Accounting Literature, 30, 1-39.

Neumann, K. (2010). Ex ante governance decisions in inter-organizational relationships: A case study in the airline industry. Management Accounting Research, 21(4), 220-237. doi:10.1016/j.mar.2010.05.002

Ouchi, W. G. (1980). Markets, bureaucracies, and clans. Administrative Science Quarterly, 25(1), 129-141. doi:10.2307/2392231

Ouchi, W. G., \& Price, R. L. (1993). Hierarchies, clans, and Theory Z: A new perspective on organization development. Organizational $D y$ namics, 21(4), 62-70. doi:10.1016/0090-2616(93)90034-X

Palay, T. M. (1984). Comparative institutional economics: The governance of rail freight contracting. The Journal of Legal Studies, 13(2), 265-287.

Perry, M. K. (1989). Vertical integration: Determinants and effects. In R. Schmalensee \& R. Willig (Eds.). Handbook of industrial organization (Vol. 1, pp. 183-255). Amsterdam, Neederlands: Elsevier Science.

Piesse, J., Strange, R., \& Toonsi, F. (2012). Is there a distinctive MENA model of corporate governance? Journal of Management \& Governance, 16(4), 645-681. doi:10.1007/s10997-011-9182-5

Reuver, M. De. (2011). Governance of mobile service innovation after the walled gardens. Info, 13(1), 43-60. doi:10.1108/14636691111101874

Reuver, M. De, \& Bouwman, H. (2012). Governance mechanisms for mobile service innovation in value networks. Journal of Business Research, 65(3), 347-354. doi:10.1016/j.jbusres.2011.04.016

Rialp, J., \& Salas, V. (2002). La colaboración empresarial desde la teoría de los derechos de propiedad. Investigaciones Económicas, 26(1), 113-144.

Rosen, S. (1996). Costos de transacción y mercados de trabajo internos. In O. E. Williamson \& S. G. Winter (Eds.). La naturaleza de la empresa: Orígenes, evolución y desarrollo (pp. 104-125). México D.F., Mexico: Fondo de Cultura Económica.

Roy, M. H., \& Dugal, S. S. (1998). Developing trust: The importance of cognitive flexibility and co-operative contexts. Management Decision, 36(9), 561-567. doi:10.1108/00251749810239441

Sako, M. (1992). Price, quality and trust: Inter-firm relations in Britain and Japan. Cambridge, United Kingdom: Cambridge University Press.

Selnes, F. (1998). Antecedents and consequences of trust and satisfaction in buyer-seller relationships. European Journal of Marketing, 32(3-4), 305-322. doi:10.1108/03090569810204580

Şengün, A. E., \& Wasti, S. N. (2009). Revisiting trust and control. International Small Business Journal, 27(1), 39-69. doi:10.1177/0266242608098346

Şengün, A. E., \& Wasti, S. N. (2011). Trust types, distrust, and performance outcomes in small business relationships: The pharmacy-drug warehouse case. Service Industries Journal, 31(2), 287-309. doi:10.1080/02642060902759137
Sharma, D. S. (2002). The differential effect of environmental dimensionality, size, and structure on budget system characteristics in hotels. Management Accounting Research, 13(1), 101-130. doi:10.1006/ mare.2002.0183

Simon, H. A. (1991). Organizations and markets. The Journal of Economic Perspectives, 5(2), 25-44.

Smets, L. P. M., Oorschot, K. E., \& Langerak, F. (2013). Don't trust trust: A dynamic approach to controlling supplier involvement in new product development. Journal of Product Innovation Management, 30(6), 1145-1158. doi:10.1111/jpim.12051

Srivastava, S. C., \& Teo, T. S. H. (2012). Contract performance in offshore systems development: Role of control mechanisms. Journal of Management Information Systems, 29(1), 115-158.

Stinchcombe, A. L. (1985). Contracts as hierarchical documents. In A. L. Stinchcombe \& C. Heimer (Eds.). Organization theory and management (pp. 121-171). Oslo, Norway: Norwegian University Press.

Subramani, M. R., \& Venkatraman, N. (2003). Safeguarding investments in asymmetric interorganizational relationships: Theory and evidence. Academy of Management Journal, 46(1), 46-62.

Tessier, S., \& Otley, D. (2012). A conceptual development of Simons' Levers of Control framework. Management Accounting Research, 23(3), 171-185. doi:10.1016/j.mar.2012.04.003

Valor, J., \& Hess, M. (2002). Estrategias y sostenibilidad de portales, proveedores de acceso a internet y empresas de contenidos: Un análisis mediante la cadena de valor. Economía Industrial, 340, 3141.

Varamaki, E., \& Vesalainen, J. (2003). Modelling different types of multilateral co-operation between SMEs. Entrepreneurship \& Regional Development, 15(1), 27.

Vázquez, R., Iglesias, V., \& Alvarez-González, L. I. (2005). Distribution channel relationships: The conditions and strategic outcomes of cooperation between manufacturer and distributor. The International Review of Retail, Distribution and Consumer Research, 15(2), 125-150. doi:10.1080/09593960500049241

Waterman, D., \& Choi, S. (2011). Non-discrimination rules for ISPs and vertical integration: Lessons from cable television. Telecommunications Policy, 35(11), 970-983. doi:10.1016/j.telpol.2011.09.001

Williamson, O. E. (1989). Las instituciones económicas del capitalismo. Mexico D.F., Mexico: Fondo de Cultura Económica.

Williamson, O. E. (1991a). Mercados y jerarquías: Su análisis y sus implicaciones antitrust. México D.F., México: Fondo de Cultura Económica.

Williamson, O. E. (1991b). Strategizing, economizing, and economic organization. Strategic Management Journal, 12(S2), 75-94. doi:10.1002/smj.4250121007

Williamson, O. E. (1993). Calculativeness, trust, and economic organization. Journal of Law and Economics, 36(1), 453-486.

Williamson, O. E. (1996). Transaction cost economics and the Carnegie connection. Journal of Economic Behavior \& Organization, 31(2), 149155. doi:10.1016/S0167-2681(96)00898-o

Xie, Y., \& Peng, S. (2011). How do corporate associations influence customer relationship strength? The effects of different types of trust. Journal of Strategic Marketing, 19(5), 443-454. doi:10.1080/096525 $4 \times .2011 .565882$

Yoo, C. S. (2002). Vertical integration and media regulation in the new economy. Yale Journal on Regulation, 19, 171-300. 